\title{
Sinkhole hazard in the post-mining area of Old Copper District, Lower Silesia, Poland
}

\author{
Adam Mirek ${ }^{1}$, Pawet Piasecki ${ }^{2}$, Barbara Kowalczyk ${ }^{2}{ }^{*}$ \\ ${ }^{1}$ State Mining Authority, Katowice, Poland \\ ${ }^{2}$ KGHM Polska Miedź S.A. O/ZG Lubin, Lubin, Poland
}

\begin{abstract}
This study discusses the occurrence of sinkholes and the removal of their effects in the territory of the Old Copper District in the municipality of Lubków, Warta Bolesławiecka, located in the voivodeship of Lower Silesia. Three sinkholes appeared more than 25 years after mining activities ceased with the closure of the "Konrad" Mine of KGHM Polska Miedź S.A. The sinkholes appeared in the former mining areas in the years 2017-2018: the first in the area of the Lubichów III shaft located in the municipality of Lubków - the downcast and transport shaft of the "Lubichów" and "Konrad" mines; the second in the area of Lubichów IVa in Lubków - the ventilation shaft of the "Lubichów" and "Konrad" mines; and the third in the area of the Lubichów IVa shaft - in the village of Lubków. The "Lubin" Mine of KGHM Polska Miedź S.A. commissioned development of projects to mitigate the risk and to secure the areas and remove the dangers.
\end{abstract}

Keywords: sinkhole hazard, copper ore exploitation, Old Copper District

\section{Introduction}

The underground exploitation of deposits often results in the formation of different types of discontinuous deformations which, depending on the depth of the drifts emerge in various forms also on the surface [1-4]. The condition of the occurrence of a sinkhole on the surface is the presence of the void where the roof is formed a pressure vault and its value is dependent on the width of the headings and the properties of the rocks [5-8]. The rock material is prone to fracturing and falling down, forming a rubble at the bottom of the void. A secondary void is created above the primary void. In the case of insufficient thickness of the overcap (thickness less than the height of the fractured zone) the secondary void develops towards the surface of the terrain where it becomes visible in the form of a sinkhole (fig. 1). The presence of water activates deformation processes as it weakens the cohesion of the rocks and enables and speeds up the rock mass displacement to the void. Sinkhole hazard is identified different methods, particularly by geophysical methods [9-15].

\footnotetext{
* Corresponding author: barbara.kowalczyk@,kghm.com
} 
In Poland, there are many of post-mining terrains of sinkhole hazard after shallow exploitation of coal seams, zinc, lead, and silver ore in the Upper Silesian Coal Basin (UCSB), zinc and lead ore near Olkusz town, iron ore near Czestochowa town, brown coal near Zielona Góra and Piła, salt in the area of Wieliczka and Bochnia mines and many others, among them also in Old Copper District near Legnica town. Due to administrative subordination, the mines of the Old Copper District were in the following locations: Złotoryja area: "Lena" copper mine in Wilków (1950-1973) and "Nowy Kościół" copper mine in Nowy Kościół (1951-1968); Bolesławiec area: "Lubichów" copper mine in Lubków (1956-1959, first as an independent entity and then in the years 1960-1976 as a subsidiary of the "Konrad" mine) and the "Konrad" copper mine in Iwiny (1950-1989).

The aim of the study is presentation of the occurrence of sinkholes and the removal of their effects in the territory of the Old Copper District in the municipality of Lubków, Warta Bolesławiecka, located in the voivodeship of Lower Silesia, Poland.

a)

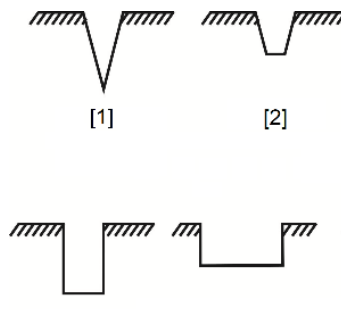

[6]
[7]

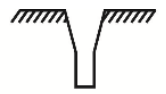

[3]

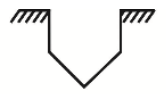

[4]

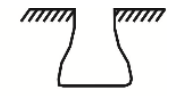

[5]

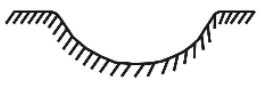

[8]

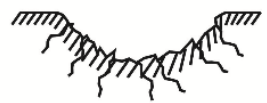

[9]

b)

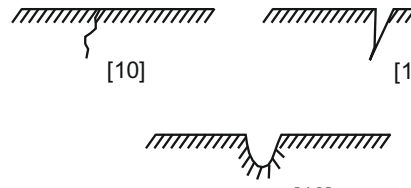

[13]

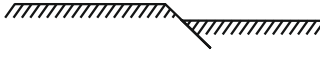

$[12]$
[11]

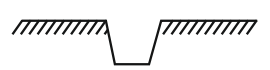

[14]

Fig. 1. Kinds of discontinuous deformations of the terrain surface in the vertical section observed in the area of shallow exploitation in USCB (on the basis [2, 3, 14]); [1] - conical sinkhole, [2] - truncated sinkhole, [3] - conical-cylindrical sinkhole, [4] - cylindrical - conical sinkhole, [5] - bell sinkhole, [6] - cylindrical sinkhole, [7] - cuboid sinkhole, [8] - continuous syncline, [9] - discontinuous syncline, [10] - crack, [11] - fissure, [12] - fault deformation, [13] - ditch, [14] - smoothed ditch

\section{Sinkhole in Lubichów III Shaft}

In the afternoon of 16 February 2017, in a private estate in the village of Lubków, in the area of the Lubichów III shaft, the emergence of mining damage in the form of a collapse of the terrain was observed in the former trunk part of the shaft (Fig. 1). The personnel of Lubin Mine took action on the same day by fencing the surrounding area, and securing the hole with a wooden structure until the form of removal of the resulting mining damage could be determined. The inhabited buildings were not damaged in any way, but the inhabitants of the building located approximately $10 \mathrm{~m}$ from the shaft (former building of the extraction machine) were relocated.

The Lubichów III shaft is in the southwest part of the "Lubichów" mining area, and was sunk between 1958 and 1961. It used a ceramic brick wall lining with cement mortar. The internal diameter of the shaft lining was $4.0 \mathrm{~m}$, lining thickness of $0.5 \mathrm{~m}$ and shaft depth of $239.3 \mathrm{~m}$. It was used as the downcast and transport shaft until 1975, when the deposit became depleted. The decision to close the "Lubichów" mining area was taken, and the remaining drifts of the mine were liquidated, including the shafts of Lubichów III and Lubichów IV. 
The shaft is marked as liquidated on the maps of the mine workings operating after the period of liquidation [16].

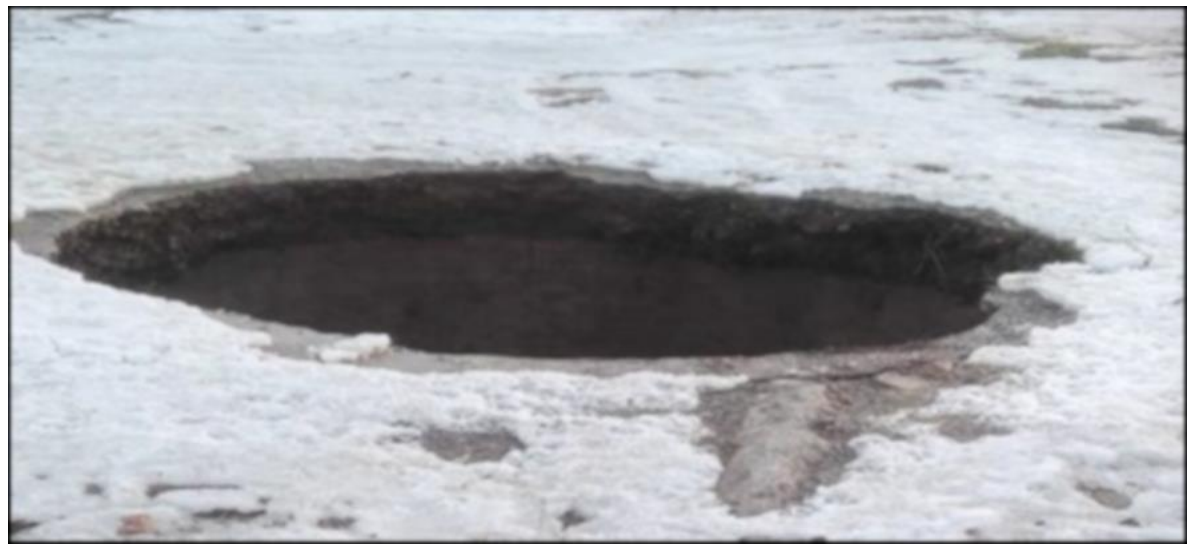

Fig. 2. Open part of the Lubichów III shaft on the day of the mining damage occurrence

The surveying services of "Lubin" Mine determined the size of the sinkhole using laser scanning. The diameter of the sinkhole was about $4.1 \mathrm{~m}$ and roughly corresponded to the diameter of the closed shaft. The gap after the shaft barrel was exposed in the sinkhole and the trunk part of the shaft was $0.45 \mathrm{~m}$ below the ground. There were no deformations found in the ground around the shaft lining except for the bottom edge part of the shaft hole resulting from damage to its integrity on the edge of the cave-in. There was no depression of the surface outside the shaft, which indicates the stability of the orogen around the shaft barrel [16]. The following steps were taken to establish and document the ground-water conditions: core drilling of seven holes in the area from the bottom of the shaft to a depth of about $20-22 \mathrm{~m}$; laboratory tests of the properties of the ground collected from the cores; and two tests by impact probing. The results indicated the physical and mechanical properties of the terrain in the area of the shaft; no basic groundwater level; absence of any cavities or hollow ground in the surveyed ground. This was a very important observation for the assessment of land stability around the shaft. A space in the shaft barrel unfilled with the filling material was exposed in the cave-in, with a water surface at a depth of about $39 \mathrm{~m}$ below the surface level.

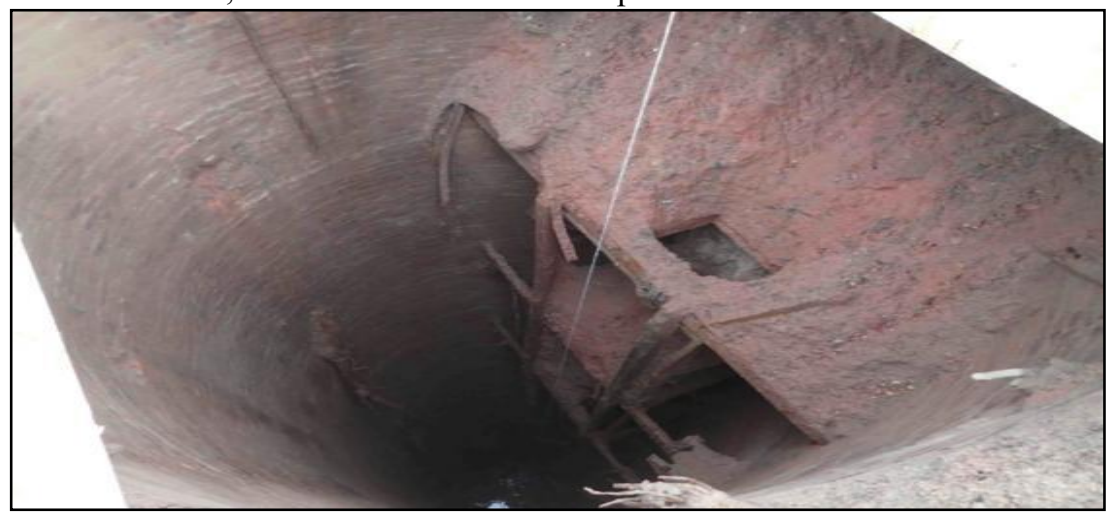

Fig. 3. The inside of the Lubichów III shaft - the entire shaft lining 
On visiting the site, it was observed that the construction for the ladder compartment as well as the shaft girders and the hoisting shaft guides were built on the side of the ladder compartment. The presented section of the lining lacks beams that would separate the hoisting compartment. There was a visible overhang on the remains of construction of the ladder compartment which probably was a left-over after backfilling the shaft with rock material from the mining dump (Fig. 3).

This overhang prevented the identification of the integrity of the shaft inlet located at a depth of $6.0 \mathrm{~m}$ under the ground level directly below the deck of the ladder compartment [16]. KGHM Cuprum performed indicative measurements of the level of the water mirror on 30 March 2017. They showed stabilisation at a depth of approximately $39-40 \mathrm{~m}$, with a test based on lowering the sinter below the mirror of the water at a depth of about $54 \mathrm{~m}$ below the surface.

The liquidation of the mining damage in the region of Lubichów III included the capping of the shaft inlet at its trunk and safeguarding the trunk part of the shaft with a reinforced concrete slab cap. This ensured full security of the shaft, both for the users of facilities located in its vicinity as well as for the environment. For the duration of the time needed to prepare the project fully and analyse the results obtained from the drilled holes, the shaft was fenced and secured with a wooden structure. The site was also monitored. The following actions were taken on the basis of the project to liquidate the collapsed Lubichów III shaft: uncovering of the shaft barrel (Fig. 4); filling the cavity in the shaft barrel; filling the interior of the shaft with crushed basalt stone to the depth of approximately $55 \mathrm{~m}$; making of a reinforced concrete slab of $7.5 \times 7.5 \times 0.5 \mathrm{~m}$ in a central position above the shaft, including insulation and placing of an inspection hole (Fig. 5); to monitor the interior of the shaft, with an inspection planned for July 2019 to determine whether the filling material level has changed and requires further filling; covering of the reinforced concrete slab with soil and return of the land for use by the owner of the property.

\section{Sinkhole in Lubichów IVa shaft}

Mining damage in the form of a collapse of the terrain in the trunk part of the Lubichów IVa ventilation shaft (Fig. 6) was observed on private agricultural land in Lubkowo [17]. The exact date of its occurrence is unknown. The cave-in was reported by the owner of the parcel in April 2018 and a notification delivered concerning its location (Lubichów IVa shaft area).

The Lubichów IVa shaft was built in the south-western part of the "Lubichów" mining area. It was a ventilation shaft, with a shaft lining diameter of $4.0 \mathrm{~m}$, depth of approximately $40.9 \mathrm{~m}$ and trunk level of the shaft of $+218.4 \mathrm{~m}$ above sea level. The shaft was connected with the ventilation drift. There is no shaft lining construction data and its equipment to be found. It is $250 \mathrm{~m}$ away from the Lubichów III shaft. No data was found on how the shaft was put out of service, but it can be assumed that took place at the same time as the Lubichów III shaft [17].

The size of the sinkhole was determined by the "Lubin" Mine surveying services. The cave in is $0.74 \mathrm{~m}$ in its deepest part with a diameter of approximately $4.0 \mathrm{~m}$. The trunk part of the shaft was invisible and the space of the shaft barrel remains covered. It was not possible to identify the material used to fill the shaft barrel [17]. The integrity of the ground on the edge of the deformation was unspoilt and there was no sedimentation of the surface in the area around the shaft. Due to the way the area was used the surface of the land was covered with vegetation, with dead shrubby vegetation visible in the sinkhole. 


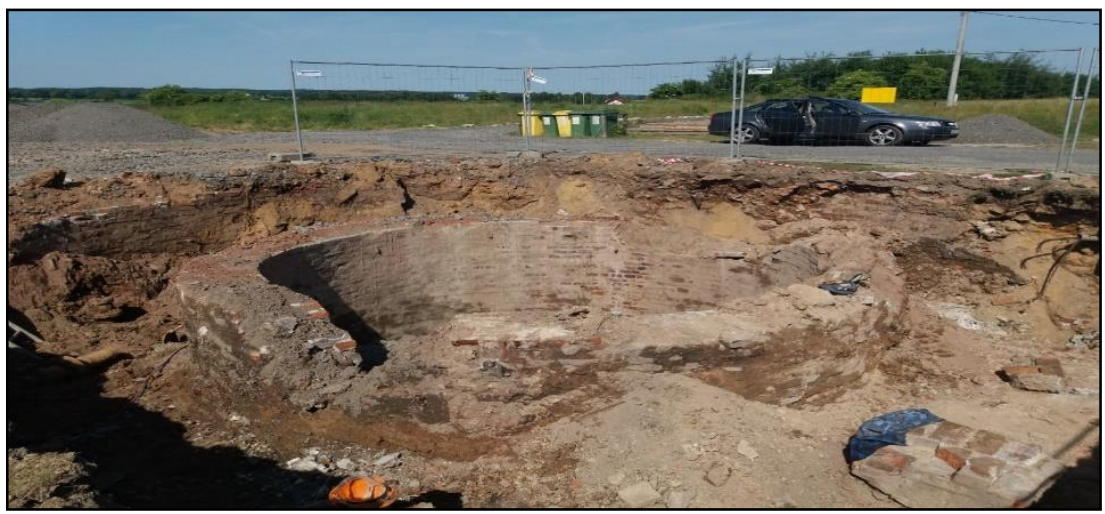

Fig. 4. Exposed Lubichów III shaft barrel.

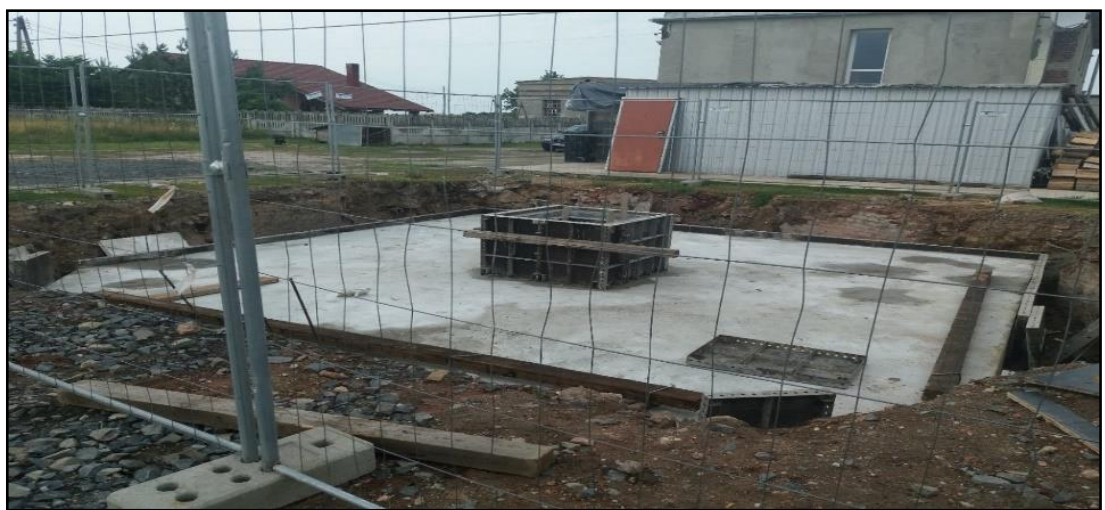

Fig. 5. Reinforced concrete slab with inspection hole securing the Lubichów III shaft barrel.

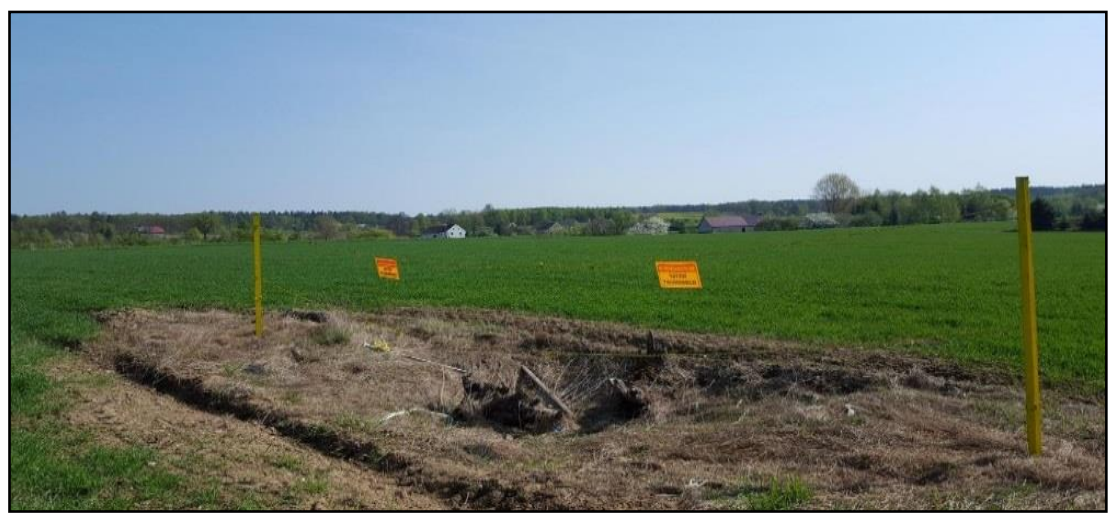

Fig. 6. The sinkhole in the trunk part of the Lubichów IVa shaft. 


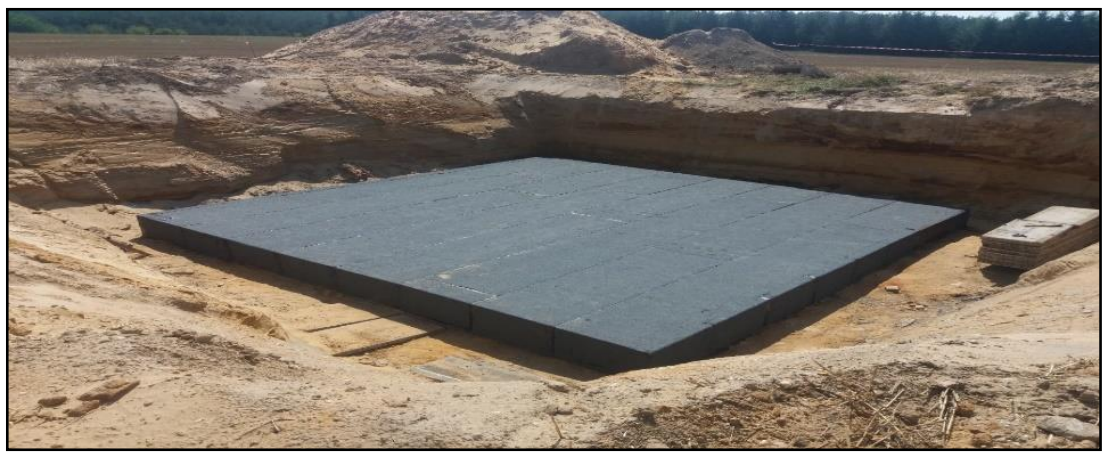

Fig. 7. Reinforced concrete slab approx. $3 \mathrm{~m}$ under terrain level, dimensions: $7.0 \times 7.0 \times 0.5 \mathrm{~m}$

The site was monitored throughout the preparation of the project, for the time needed for the ground-penetrating radar survey (GPR) and the analysis of the results. The following actions were taken following the project: a $10.5 \mathrm{~m} \times 10.5 \mathrm{~m}$ excavation (approx. $3 \mathrm{~m}$ deep) to uncover the shaft barrel which in turn was not found at the designated depth; it was decided not to continue the excavations after consulting the company implementing the project; at the level reached by excavation works a $7.0 \times 7.0 \times 0.5 \mathrm{~m}$ reinforced concrete slab without a revision hole was placed in the central position over the shaft - the slab was insulated (Fig. 7); the cave-in was filled with sand of appropriate fraction and humus to restore the land for use by the owner of the parcel.

\section{Unidentified sinkholes in the region of Lubichów IVa}

A non-continuous deformation of the area of unknown origin in the form of a rupture was revealed in April 2018 in the village of Lubków in the south-western part of the mining area "Lubichów". The sinkhole was created during field work using agricultural equipment. The deformation was about $60 \mathrm{~m}$ south-west of the Lubichów IVa ventilation shaft. The elevation of the terrain near is at an altitude of about $216 \mathrm{~m}$ above sea level. Measurements have shown that it has a circle shape of approximately $4.0 \mathrm{~m}$ in diameter. The estimated depth of the sinkhole is approximately $2.0 \mathrm{~m}[18]$.

Deformation was caused by the collapse of the terrain into the orogen to a depth of about $2 \mathrm{~m}$. It was a circular rupture due to the geometry in the horizontal section. The rupture walls were steep near the edge of the surface while the deeper part was shaped as a conical funnel (Fig. 8). The ground was damp and not covered with vegetation inside [18]. There was no subsidence of the terrain or other forms of deformation in the perimeter. The area around the sinkhole was secured by a ring-fence and signage (Fig. 9) the genesis of the sinkhole could not have been determined and it was impossible to confirm the stability of the soil.

It should be considered that the formation of non-continuous sinkhole is of anthropogenic origin due to its location and nature because, according to all available indications, it constitutes an unintentional side effect of the former mining activity of "Lubichów" Mine. All things considered, it can be assumed that the "Lubichów" sinkholes were mainly influenced by the following factors [18]: location in the shallow located drifts of "Lubichów" mine, including above all the ventilation drift pos. 52; insufficient thickness of the rock mass in the overcap for filling the void; the hydrogeological situation in the region related to the restoration of groundwater level; the activity of rainwater infiltrating into the ground; presence of the active fault in the area. 


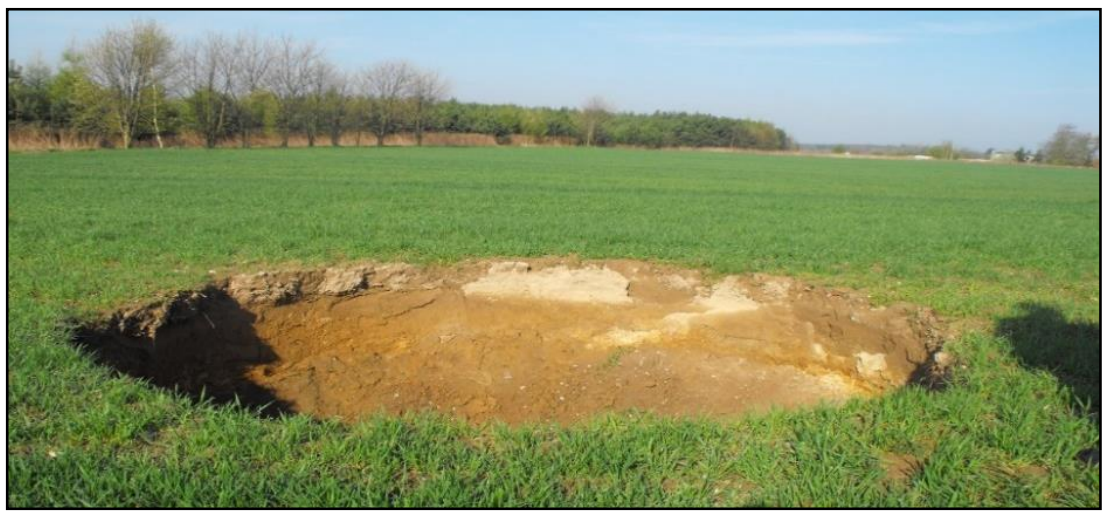

Fig. 8. The sinkhole in Lubichów IVa shaft area.

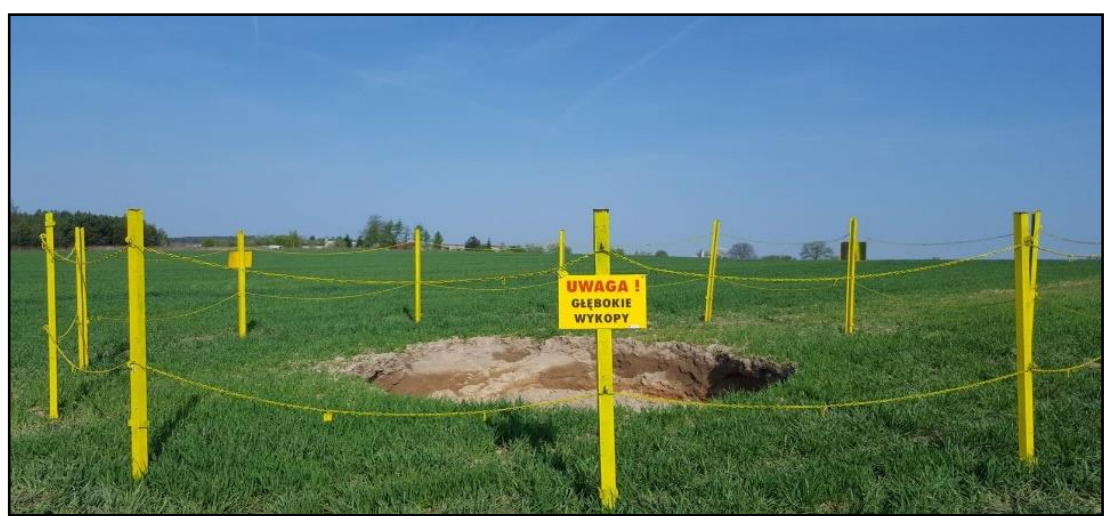

Fig. 9. Secured sinkhole in Lubichów IVa shaft area.

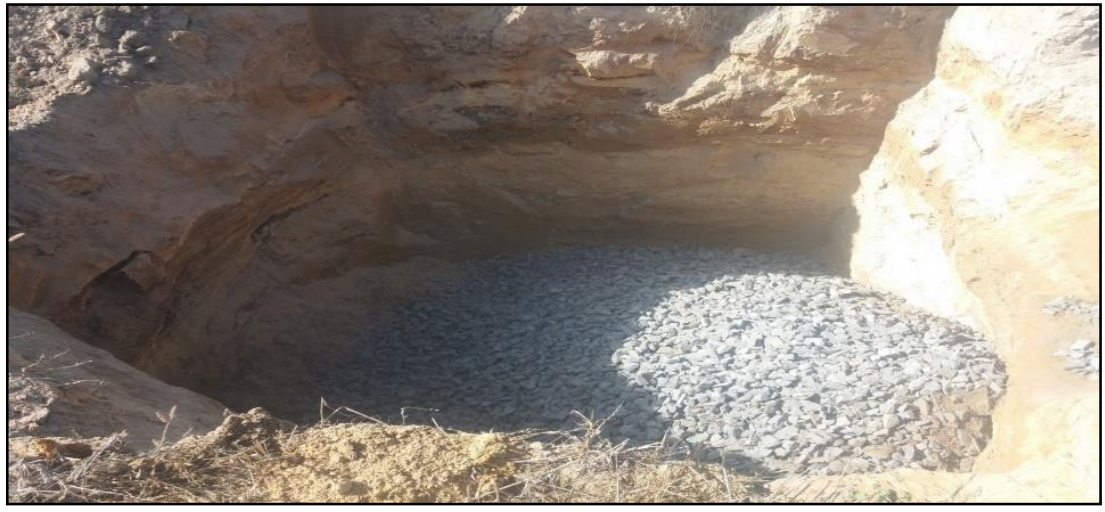

Fig. 10. The filling of the landslide located in the area of the Lubichów IVa shaft.

The site was monitored throughout the preparation of the project, for the time needed for the ground-penetrating radar survey (GPR) and the analysis of the results, the sinkhole was adequately secured. It was decided to secure the sinkhole by deepening it and filling with crushed basalt rock of the indicated fraction (Fig. 10) and to build a fence around about 0.10 hectares of the parcel (Fig. 11) in order to monitor the position of the level of the upper surface of the filling for a period of three years until 06 September 2021 based on part II of 
the project on the liquidation of unidentified sinkhole located near the Lubichów IVa shaft and the results of the GPR survey of the land.

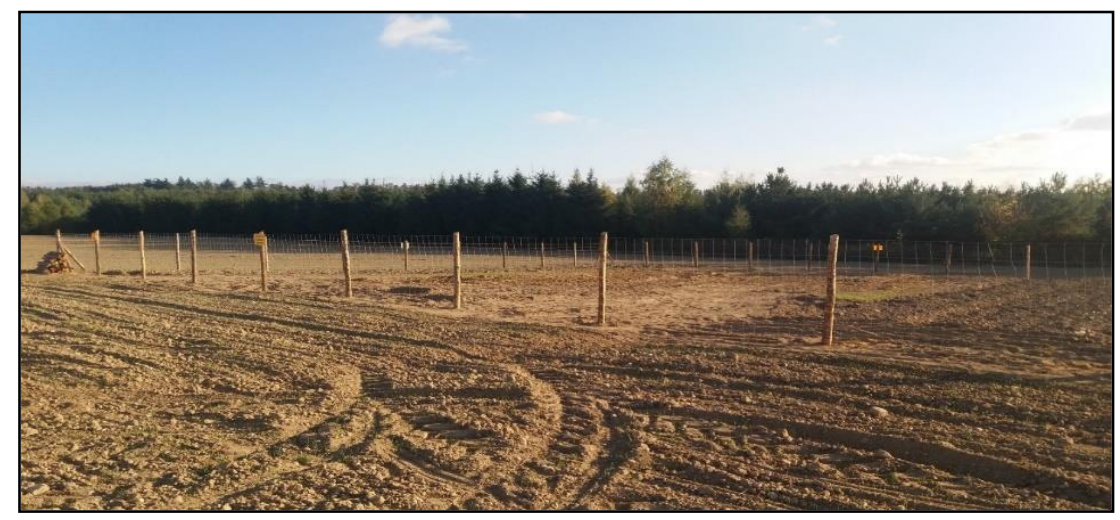

Fig. 11. The fence around the area of the landslide under surveillance.

\section{Summary}

Mining damage can become apparent in the mining areas of the Old Copper Belt although the mines there have long been excluded from exploitation, the mines have been closed for years and the mining sites have been liquidated. Phenomena that are described in the paper may occur. The damage caused in the Lubichów III and Lubichów IVa shafts protected by crushed basalt rock backfilling and covered on top with reinforced concrete slab ensures that the damage of this kind in this place will not happen again. Treatment of the non-continuous deformation (sinkhole) in the Lubichów IVa shaft area by backfilling with crushed basalt rock does not mean the damage will not reoccur. Hence, the decision to put a fence around the sinkhole site and constant monitoring of the site for three years seems appropriate.

\section{References}

1. F. G. Bell, Bulletin of the International Association of Engineering Geology 37, 91-98 (1988) doi: 10.1007/BF02590374.

2. M. Chudek, W. Janusz, J. Zych, Studium dotyczace stanu rozpoznania tworzenia się $i$ prognozowania deformacji nieciagłych pod wplywem podziemnej eksploatacji złóż (Study on recognition of formation and forecasting of discontinuous deformations under the influence of underground exploitation). Zeszyty Naukowe Politechniki Śląskiej 141, Gliwice (1988) (in Polish).

3. E. Popiołek, Z. Pilecki (eds.), Ocena przydatności do zabudowy terenów zagrożonych deformacjami nieciaglymi za pomoca metod geofizycznych (Assessment of areas threatened with discontinuous deformations for building suitability using geophysical methods). Wyd. IGSMiE PAN, Kraków, (2005).

4. B. N. Whittaker, D. J. Reddish, Subsidence behaviour of rock structure, w: Comprehensive rock engineering - principles, practice and projects, J.A. Hudson ed., Pergamon Press, Oxford, New York (1993).

5. P. Strzałkowski, Arch. Min. Sci. 60, 1, 63-71 (2015) doi: 10.1515/amsc-2015-0005 
6. H. Marcak, Z. Pilecki, Some Geophysical and Geomechanical Remarks on Recognition Sinkhole Processes in Post-Mining Areas, Proc. 12th European Meeting of Environmental and Engineering Geophysics, 4-6 September 2006, Helsinki, Finland (2006).

7. Sałustowicz A., Zarys mechaniki górotworu (Outline of rock mass mechanics). Wyd. Śląsk, Katowice, (1968), (in Polish).

8. Z. Pilecki, A. Baranowski, Estimation of dimension of a regular-type sinkhole activated by abandoned shafts, Publications of the Institute of Geophysics, Polish Academy of Sciences M-29, 395, 271-279 (2006).

9. Z. Pilecki, Gospod. Surowcami Min. 25, 3, 319-331 (2009).

10. G. C. Colley, The detection of caves by gravity measurements, Geophys. Prospect. 11, 1-10 (1963).

11. Z. Pilecki, The role of geophysical methods in the estimation of sinkhole threat in the post-mining areas of shallow exploitation in the Upper Silesian Coal Basin, Poland, Gospod. Surowcami Min. 24, 3/1, 27-40 (2008).

12. J. C. Cook, Seismic mapping of underground cavities using reflection amplitudes, Geophysics 30, 4, 527-538 (1965).

13. A. Kotyrba A., L. Kortas, Sinkhole hazard assessment in the area of abandoned mining shaft basing on microgravity survey and modelling - Case study from the Upper Silesia Coal Basin in Poland. Journal of Applied Geophysics 130: 62-70, (2016), DOI: 10.1016/j.jappgeo.2016.04.007.

14. Z. Pilecki, Geophysical identification of voids and loosened zones in the shallow subsurface of post-mining areas. E3S Web of Conferences 66, 01001, doi.org/10.1051/e3sconf/20186601001 (2018).

15. E. Pilecka, D. Szwarkowski, An application of the ground laser scanning to recognise terrain surface deformation over a shallowly located underground excavation. E3S Web of Conferences 24, 01006 (2017), DOI: 10.1051/e3sconf/20172401006.

16. KHGM Cuprum Sp. z o.o. - CBR in Wrocław, Removal of the hazard by capping the Lubichów III shaft in Lubkowo of the former copper ore mine "Konrad", Wrocław (2017) (in Polish).

17. KHGM Cuprum Sp. z o.o. - CBR in Wrocław, Removal of the hazard by backfilling the cave-ins of Lubichów IVa and adjacent of unidentifiable sinkholes in Lubkowo after the former copper ore KONRAD - part I, Wrocław (2018), (in Polish).

18. KHGM Cuprum Sp. z o.o. - CBR in Wrocław; Removal of the hazard by backfilling the cave-ins of Lubichów IVa and adjacent of unidentifiable sinkholes in Lubkowo after the former copper ore KONRAD - part II, Wroclaw (2018), (in Polish). 